\title{
Maria Cieśla
}

\author{
MOJŻESZOWICZ, GORDON, ICKOWICZ: \\ THE JEWISH ECONOMIC ELITES \\ IN THE GRAND DUCHY OF LITHUANIA \\ (SEVENTEENTH AND EIGHTEENTH CENTURY)
}

\section{I \\ INTRODUCTORY REMARKS}

The Jews formed the largest religious-ethnic minority group in the Polish-Lithuanian Commonwealth; ${ }^{1}$ it is estimated that they accounted for circa 9 per cent of the country's population in the late eighteenth century. They mostly formed part of urban populations, with a share of 40 per cent to 50 per cent among the country's burghers. The Jews played a significant part in the economic life, monopolising the taproom income leaseholds in private estates, and holding a strong position in trading operations.

The history of the Commonwealth's Jewry has enjoyed increasing interest in the last dozen-or-so years, yielding studies on the minority's history and culture, and on its functioning within a Christian society. ${ }^{2}$ Yet, even if read cursorily, these studies attest that the Jews

${ }^{1}$ Jerzy Topolski, 'On the Role of the Jews in the Urbanization of Poland in the Early Modern Period', in Andrzej K. Paluch (ed.), The Jews in Poland (Cracow, 1992), 47; Jakub Goldberg, Juden in Polen und Litauen. Warum und auf welche Weise geht man ihrer Geschichte nach (Leipzig, 1996). I have not included the GreekCatholic Ruthenians among the religious-ethnic minorities. For more on the Commonwealth's religious-ethnic minorities, see Józef Gierowski, 'Rzeczpospolita wielu narodów i wyznań', in idem, Na szlakach Rzeczypospolitej w nowożytnej Europie (Cracow, 2008), 81-6.

${ }^{2}$ On the development of Jewish historiography, see Moshe Rosman, 'Między koniecznością a modą. Uwagi nad przeszłością i przyszłością badań nad dziejami Żydów w Polsce', in Marcin Wodziński and Anna Michałowska-Mycielska (eds.), Małżeństwo z rozsądku? Żydzi w społeczeństwie dawnej Rzeczypospolitej (Wrocław, 2007), 131-44; more generally on Jewish historical research and studies, see Moshe 
are usually approached as a homogenous, impersonal group. The focus on their internal splits, differences in the social status is a rare thing; one exception is studies on individuals, with men of religious authority or heretics enjoying the greatest interest. ${ }^{3}$ The role of Jews in the Commonwealth's economic life is appreciated and described in detail, whilst on the other hand, the names of Jewish merchants, bankers, leaseholders or publicans are merely unknown to us, and there is nothing we could say of their private lives. And yet the question of who they were, and what the drivers were that appeared crucial to their economic success, seems interesting. However, to give an answer is not easy. This is due to the condition of the extant sources; a majority of the materials concerning the Jews are documents produced by the Christian authorities: there are no private Jewish archives surviving, and there are virtually no ego-documents that we could make use of. The Christian sources describe the Jews from the standpoint of external observers, most of the pieces of information therein comprised regarding economic contacts, and nothing beyond. It has moreover to be borne in mind that in the period in question, Jews did not use surnames: the Polish-language sources describe them by their 'first' names and a cognomen formed from the father's name, which renders the research on individuals even more difficult. With such a base at hand, it is very hard to describe the daily lives of Jewish merchants, leaseholders or innkeepers - a task deliverable only for some groups. The best graspable are exponents of the Jewish economic elite, the richest members of Jewish communities, who owing to their large-scale businesses conducted with the Christian community - not only made appreciable fortunes but also earned a high social standing. The crucial thing for the historian, however, is that their close contacts with their Christian partners caused that a relatively considerable number of source documents concerning

Rosman, How Jewish is Jewish History? (Oxford, 2007), esp. pp. 82-110; Goldberg, Juden in Polen und Litauen; Gershon D. Hundert, 'On the Problem of Agency in 18th-Century Jewish Society', in Adam Teller (ed.), Studies on the History of the Jews in Old Poland: In Honor of Jacob Goldberg (Scripta Hierosolymitana, 38, Jerusalem, 1998), 82-9.

${ }^{3}$ Moshe Rosman, Founder of Hasidism: A Quest for Historical Ba'al Shem Tov (Contraversions: Critical Studies in Jewish Literature, Culture, and Society, Berkeley, 1996); Pawel Maciejko, The Mixed Multitude: Jacob Frank and the Frankist Movement 1755-1816 (Philadelphia, 2011). 
those Jews have been preserved. Still, no private archival resources or ego-documents are available for them, either.

The notion of economic elite is relative, and calls for a more precise definition. On the grounds of the existing sociological and historical studies, especially those focused on the West-European Hofjuden, ${ }^{4}$ I have assumed the following determinants of 'elite': a disparate (i.e. privileged) legal and social position, close contacts with the centre of the political and economic authorities; affluence; and, a degree of acculturation. Since my present analysis focuses on the economic elites, the determinations such as descent and educational background, otherwise traditional for the Jewish community, remain beyond the scope of interest and definition. Within it are, definitely, individuals that formed the economic elite, but developing a prosopographic study is not the objective of my considerations. The arguments following below ought rather to be approached as a collection of case studies, presenting the histories of several Jewish potentates who originated from the royal as well as magnate agents' milieus. The following issues, considered in their long duration, are subject to my analysis: career routes, strategies of activity, and styles

${ }^{4}$ Peter Burke, Venice and Amsterdam: A Study of Seventeenth-Century Elites (London, 1974); Antoni Mączak, Rządzacy $i$ rzadzeni. Wtadza $i$ spoteczeństwo $w$ Europie nowożytnej (2nd edn, Warsaw, 2002). The research on the elites in the Polish-Lithuanian Commonwealth society have hitherto focused almost exclusively on nobility elites, and hence are not of much use for my present purpose; cf. Edward Opaliński, Elita władzy w województwach poznańskim i kaliskim za Zygmunta III (Poznań, 1981); Krzysztof Chłapowski Elita senatorsko-dygnitarska Korony za czasów Zygmunta III $i$ Wtadystawa IV (Warsaw, 1996); Stefan Ciara, Senatorzy i dygnitarze koronni $w$ drugiej polowie XVII $w$. (Wrocław etc., 1990); Teresa Zielińska, Magnateria epoki saskiej. Funkcja urzędów $i$ królewszczyzn $w$ procesie przeobrażeń warstwy spotecznej (Wrocław and Warsaw, 1977). The most recent studies worth mentioning include: Maciej Ptaszyński, Narodziny zawodu. Duchowni luterańscy $i$ proces budowania konfesji w Księstwach Pomorskich XVI/XVII w. (Warsaw, 2011). The West-European Hofjuden enjoy incessant interest among researchers; cf. Selma Stern, The Court Jew: A Contribution to the History of Absolutism in Central Europe (Philadelphia, 1950); Vivian B. Mann, Richard I. Cohen, and Fritz Backhaus (eds.), From Court Jews to the Rothschilds: Art, Patronage, and Power, 1600-1800 [Exihibition Catalogue] (Munich and New York, 1996); Rotraud Ries and J. Friedrich Battenberg (eds.), Hofjuden: Ökonomie und Interkulturalität. Die jüdische Wirtschaftselite im 18. Jahrhundert (Hamburger Beiträge zur Geschichte der deutschen Juden, 25, Hamburg, 2002); Thekla Keuk, Hofjuden und Kulturbürger. Die Geschichte der Familie Itzig in Berlin (Jüdische Religion, Geschichte und Kultur, 12, Göttingen, 2011). 
of life. I have limited my considerations to the area of the Grand Duchy of Lithuania (hereafter: GDL), since certain differences in the legal system and social structure caused that the Jews in GDL found it easier than in the Crown to develop their careers in a Christian environment. ${ }^{5}$ The source base used for the present purpose is formed of documents produced by the royal chancellery, courthouse records and materials from magnate archives. ${ }^{6}$

Prior to embarking on a detailed analysis, two issues require being reflected upon: the numerical force of the group being described, and the sense of identity of its members.

The population in question was small in number, and the lifestyle of its members proved untypical against the Jews populating GDL. ${ }^{7}$ To precisely define how many members there were is difficult. The Lithuanian Metrica's Books of Inscriptions has forty royal privileges entered for Jewish individuals between 1632 and $1764 .^{8}$ It however seems

${ }^{5}$ Maria Cieśla, 'W jednej Rzeczypospolitej Żydzi polscy czy litewscy', Gal-Ed, 23 (2013), forthcoming.

${ }^{6}$ Subject to analysis are the materials presently kept at the Archiwum Główne Akt Dawnych [Central Archives of Historical Records], in Warsaw - the Archiwum Radziwiłłowskie [Radziwiłł Archive] (hereafter: AR); the Lietuvos Valstybès Istorijos Archyvas [The Lithuanian State Historical Archive], in Vilnius (hereafter LVIA) - the Lietuvos Metrika [the Lithuanian Metrica] (hereafter: LM), and the Senai Aktai (hereafter LVIA, SA); the Lietuvos Mokslu Akademija, Vrublevskiu Biblioteka [The Wroblewski Library of the Lithuanian Academy of Sciences], in Vilnius (herafter: LMAB); the Natsional'nyı̆ Istoricheskii Arkhiv Belarusi [National Historical Archive of Belarus], in Minsk (herafter: NIAB) - Radzivill Kniaz'ya (The Radziwiłł Family Archive), fond 694.

${ }^{7} \mathrm{~S}$. W. Baron estimates the population of Jewish economic elites of the late 18th century as ca. $2-3 \%$ of the Jewish society - an estimation which seems somewhat overstated, though. Cf. Salo W. Baron, Arcadius Kahan, and Nachum Gross, Economic History of the Jews (Jerusalem, 1975), 69.

${ }^{8}$ For the entire period under analysis, the royal charter was granted to the following individuals: Mojżesz Łazarowicz (LM, 103, 23 March 1632); Łazarz Mojżeszowicz (ibidem, 23 March 1632); Samuel Mojżeszowicz (ibidem, 23 March 1632); Jonasz Mojżeszowicz (LM, 130, 13 Dec. 1657); Heliasz Izaakowicz (LM, 140, 19 Aug. 1683); Jozue Moszkowicz Marek (LM, 142, 1689); Hirsz Semiakowicz (LM, 146, 3 Nov. 1692); Irsz [Hirsz] Izraelowicz (LM, 149, 20 Feb. 1698); Józef Szapszewicz (LM, 154, 25 Feb. 1710); Jankiel Jachimowicz (ibidem, 25 Feb. 1710); Pinkas Izaakowicz (LM, 159, 10 Jan. 1713); Lewin Salomon Hamburski (ibidem, 21 Feb. 1713); Aaron Gordon (ibidem, 16 March 1713); Zelman (ibidem, 27 Nov. 1714); Hezel Giecowicz (ibidem, 27 Nov. 1714); Salomon Gordonowicz (ibidem, 24 Feb. 1717); Samuel Izraelowicz (ibidem, 24 Feb. 1717); Kochman Izaakowicz 
that not all the documents were entered in the Metrica; moreover, it is completely impossible to determine how numerous the group of so-called magnate agents was; their activities became particularly significant in the eighteenth century. ${ }^{9}$

It is very hard to tell whether members of the economic elite had a sense of belonging to a separate social group. However, this inclusivity was only reinforced by a well-thought-out matrimonial policy - otherwise, a seemingly unsatisfactory factor. An excellent example is offered by the Łazarowicz-Mojżeszowicz family, to which the most influential seventeenth-century royal agents were born. ${ }^{10}$ Their preferred option was marriages among close relatives: uncles would marry nieces; matrimonies also happened between cousins. ${ }^{11}$

(ibidem, 25 Nov. 1718); Pinkas Markowicz (ibidem, 17 March 1720); Abraham Markowicz (ibidem, 3 April 1720); Henzel Eliaszowicz (ibidem, 3 April 1720); Wulf Joelowicz (ibidem, 3 June 1720); Judko Szmoyłowicz (ibidem, 14 Dec. 1720); Józef Abramowicz (LM, 160, 28 Feb. 1721); Józef Mendelowicz (ibidem, 28 Feb. 1721); Wewel Józefowicz (LM, 162, 24 Nov. 1724); Mendel Leybowicz (LM, 169, 23 Feb. 1733); Mojżesz Beniamin Szpeyer (ibidem, 4 Dec. 1735); Izrael Jonaszowicz (LM, 177, 14 Nov. 1748). Apart from the individuals named in the deeds conferring the title of factor, the sources mention a group of Jews actively cooperating with the Court and the Treasury, for whom no confirmation of official conferment of such title has been found in LM. Those included: Izaak Fajbisiewicz (LM, 119, 25 March 1645); Izaak Chackielewicz (LM, 129, 13 April 1665); Icek Izraelowicz (ibidem, 17 April 1654); Icko Zelmanowicz Stołowicki, Szmerko Zelmanowicz Stołowicki (Regesty i nadpisy. Svod materialov dlya istorii evreev v Rossii [80 g. - 1800 g.], 3 vols. [Saint Petersburg, 1899-1913], ii, no. 1278; 16 July 1693); Leyba Zusmanowicz (LM, 369); Ajzyk Heliaszowicz (LM, 146, p. 711, 24 July 1693); Pinkas Mojżeszowicz (LM, 159, 24 Feb. 1717), Józef Eliaszowicz (ibidem, 24 Feb. 1717).

${ }^{9}$ Insofar as the easiest way to pursue a career in the Christian environment was for the seventeenth-century Jews to cooperate with the royal court and the court treasury, magnate agents had better opportunities opened for them in the 18th c.; see Adam Teller, 'The Legal Status of the Jews on the Magnate Estates of Poland-Lithuania in the 18th Century', Gal-Ed, 15-16 (1997), 49. On the increased social importance of magnate courts, see Andrzej Pośpiech and Wojciech Tygielski, 'The Social Role of Magnates' Courts in Poland (From the End of the 16th Century up to the 18th Century), Acta Poloniae Historica, 43 (1981), 75-100.

${ }^{10}$ Maria Cieśla, 'Łazarz Mojżeszowicz - przykład żydowskiej kariery w Wielkim Księstwie Litewskim', Kwartalnik Historyczny, cxii, 4 (2005), 5.

${ }^{11}$ Łazarz Mojżeszowicz was married to his niece, daughter of Jonasz Mojżeszowicz; his sororal nephew Pinkas Samuelowicz was married to his cousin, another daughter of Jonasz Mojżeszowicz; LM, 331, no. 39, 'The Decree between Wojciech Zdrojewski, a nobleman, and Jonasz Mojżeszowicz, a Jew of Brest, and 
Marriages of this sort are admitted by the Jewish religious law, but tend to be a rare occurrence, particularly in the Ashkenazi circle. Endogamic wedlock was also practised in the milieu of Christian economic elites of the contemporary Europe - a peculiar way of investmentmaking, applied to prevent divisions of the ancestral property. The in-family matrimonial policy was applied possibly because the Jewish economic elite in GDL was scarce, to the extent that the EazarowiczMojżeszowiczs would not be able to find the deserving partners for their daughters; the other reason might be that they did not have contacts with the West-European Jewish economic elites. The Ickowicz brothers, Jewish potentates who in the eighteenth century collaborated with the Radziwiłł family, adhered to a different matrimonial strategy: through a suitably matched marriage, they sought to establish contacts with the international Jewish economic elite. ${ }^{12}$

\section{II}

\section{LEGAL AND SOCIAL STATUS}

The unique legal position was one of the major, external determinants of membership in the Jewish economic elitist group. The legal status was formally altered upon issuance of a privilege. The royal and magnate agents both formed groups that were internally much diversified. Among members of the former were, for instance, the royal secretaries Łazarz Mojżeszowicz and Heliasz Izaakowicz. ${ }^{13}$ The most influential magnate agents received official functions and titles within the magnate estates: Szmoyła Ickowicz was appointed Cashier (Treasurer) General for the estate of Anna Radziwiłł, née Sanguszko. ${ }^{14}$ The basic responsibilities the royal and lordly factors were tasked with was providing supplies to the royal/magnate courts; this activity was combined with public or private income lease-holding.

his daughter Szprincea Pinkasowa', 13 Aug. 1646. Also, cf. Mączak, Rządzacy i rządzeni, 171; Cornelia Aust, 'Commercial Cosmopolitans: Networks of Jewish Merchants between Warsaw and Amsterdam 1750-1820' (Ph. D. thesis, University of Pennsylvania, 2010), 64-81.

12 A. Teller, כסף כוח והשפעה. היהודים באהוזות רדז'יוויל בליטא במאה הי"81. (Jerusalem, 2006), 121.

${ }^{13}$ Cieśla, 'Łazarz Mojżeszowicz', 14. A titular post of royal secretary is meant.

${ }^{14}$ Ibidem; Teresa Zielińska, 'Kariera i upadek żydowskiego potentata w dobrach radziwiłłowskich w XVIII wieku', Kwartalnik Historyczny, xcviii, 3 (1991), 36. 
Those Jews who received the official title of royal agent were transferred under the exclusive royal jurisdiction (thus becoming put in a different position than their fellow brothers who were subject to royal officials' jurisdiction), received the right to get settled in the country's entire territory, including in the towns where the de non tolerandis Judaeis privilege was in force. They were also granted a number of economic privileges, such as exemptions from taxes, customs duties and any other duties and obligations.

A number of customary laws were also related to the royal agent title - not specified in the charters, and often inconsistent with the binding regulations. I should like at this point to draw the attention to the privileges, extensively applied in GDL, that directly informed the development of the careers of Jewish potentates. The right to own a land comes first. Transferral of the perpetual right to a grange or a life leasehold was regarded as a sort of gratuity paid out of the state treasury. This is how Jews most frequently turned into owners of farms that had before then belonged to the 'table [king's] estates'. ${ }^{15}$ Some estates were purchased or received in exchange for settlement of debts. ${ }^{16}$ The other type of privilege was the possibility of receiving safe-conducts issued by the royal chancellery, in spite of the Statutes of Lithuania banning the issuance of such documents. The king would intervene in case of unexpected financial problems or in conflicts with nobles or burghers. ${ }^{17}$

${ }^{15}$ LM, 432, 'Contempt of court to Godlewski, a nobleman, versus Łazarz Mojżeszowicz', 31 Jan. 1653; LM, 138, p. 222, 'Consent to Icek Faysiewicz, goldsmith of Grodno, ad cedendum [re. transference of] 12 empty wtókas [land area measurement unit] in the Grodno royal estates', 28 April 1676; NIAB, fond 1786, op. 1, sect. 2, pp. 3-4, 'Sale of the Michałowski piece-of-land, situated behind the orchard', 4 Feb. 1637. Also, cf. Cieśla, 'Łazarz Mojżeszowicz', 19.

${ }^{16}$ Akty izdavaemye Vilenskoyu Arkheograficheskoyu Kommissieyu [herafter: AVAK], vol. 29 (Vilnius, 1902), no. 146, 'Between the Berkowiczs and Franciszek Wołodkiewicz', 5 April 1700; AR, x (the Kiszka Archive), 637, pp. 28-29; NIAB, fond 1786, op. 1, sect. 4, pp. 249-50, 'Provision of piece-of-land to Jakub Szymonowicz, a Jew' (10 Dec. 1660).

17 The ban on issuance of safe-conducts to Jews was provided in the Statutes of Lithuania; as the search query at LM shows, this ban was frequently broken; see LM, 159, p. 106, 'Safe-conduct to the infidel Beniamin Szpeyer, our factor', 7 March 1713; ibidem, p. 166, 'Safe-conduct pass ad jure agendum [in compliance with the binding law] to the infidel Beniamin Szpeyer', 10 March 1713; ibidem, p. 323, 'Moratorium to the infidel Pinkas Mojżeszowicz', 24 Feb. 1717; ibidem, p. 312, 
Magnate agents also enjoyed a unique legal status; it is difficult, though, to determine all the rights vested in this particular group. Such persons functioned, in most cases, at magnate courts based on the custom, not always reinforced by a legal document; it should not be neglected that not all the magnate courts functioned according to exactly the same rules; thus, the functions and the position of Jews within them were, accordingly, diverse. However, once the formal appointment took place, they were usually granted the rights commensurable with those of Jewish royal agents. Magnate agents were exclusively subject to their magnate patron's jurisdiction; they could count on economic facilitations, and were beneficiaries of a number of additional privileges, such as residing in treasury houses, settling in places banned to the other Jews, the right to possess a land, and the symbolic right to use an ensign featuring the magnate coat-of-arms. ${ }^{18}$

Conferment of the title of royal or magnate agent implied the extension of direct royal or baronial patronage to the title holder a very important factor with respect to the social position of Jews. Many a royal or magnate agent maintained permanent, frequent and

'Moratoria to the infidel Józef Eliaszowicz', 24 Feb. 1717. The LM documents moreover contain safe-conducts for the following: Codzik and Abraham Morduchajewicz (LM, 99, no. 614, 'Safe-conduct to the Jews of Kobryn, disunited', 3 Sept. 1630); Pinkas Samuelowicz (LM, 119, p. 140, 'Safe-conduct-pass letter to Pinkas, a fugitive Jew of Brest', 17 May 1647); Abraham Salomonowicz (ibidem, p. 150, 'Safe-conduct pass of Abraham Salomonowicz, a Jew'); Wewel Józefowicz (LM, 162, pp. 219-20, 'Letter of patronage to a Jew of Szawle', 24 Oct. 1724); a conflict between Pinkas Izaakowicz and Michał Kazimierz Kociołł, Treasurer [podskarbi] - LM, 159, p. 262, 'Safe-conduct to Pinkas Izaakowicz', 27 Sept. 1717; ibidem, pp. 309-10, 'Retrenchment of the serwitorat [privilege granting rights as serwitor] for health, life, and fortune by safe-conduct letter to the infidel Pinkas Izaakowicz'; ibidem, p. 422, 'Safe-conduct from the power and potency of the Honourable Kot, the Treasurer of the GDL, to Pinkas Izaakowicz', 9 Jan. 1717; ibidem, 'Safe-conduct pass to Pinkas Markowicz, a Jew, the current serwitor of ours', 17 March 1720; a conflict between Beniamin Szpeyer and Dziechciarowicz, mayor of Mohylev ibidem, p. 106, 'Patronising safe-conduct to the infidel Mojżesz Szpeyer', 7 March 1713; ibidem, pp. 166-8, 'Safe-conduct pass ad jure agendum against the banishment of the Renowned Dziechciarowicz', 10 March 1713.

${ }^{18}$ AR, xxix, 9, pp. 193-4, 'The privilege for Mazurka'; AR, xxix, 8, p. 62, Serwitorat to Abram Usielewicz; AR, xxix, 5, pp. 223-7, 'Issuance of the passport to Howsiej Michałowicz'; Archiwum Państwowe w Krakowie [The National Archive in Cracow], Archiwum Młynowskie Chodkiewiczów [the Chodkiewicz Archive of Młynów], 2518, p. 71, Charter for Rubin Abrahamowicz. 
personal contacts with their court, reciprocally enjoying assistance in various tough situations. ${ }^{19}$ The custom of issuing safe-conducts to Jews has already been mentioned. Favouritism was a very important factor in contacts and conflicts with third parties. In lawsuits, Christian patrons took responsibility for their Jewish clients, which in practice meant that Jews would not appear as defendants or plaintiffs in person: instead, their patrons would do the task. ${ }^{20}$ There is no need to argue that the position of Jewish magnate or royal agents appearing at courts under a magnate's custody was definitely stronger than in the case of individuals that could not enjoy such backing. The Jews and the magnates had shared interests. Their service relationships often gained a personal dimension. Jewish agents exchanged extensive correspondence with their Christian patrons, predominantly focusing on financial operations. Important family events were mentioned in those letters as well: illnesses, travels, removals. The frequency at which letters were exchanged and the fact that when a Jew did not respond, his patron would be disturbed - as seemingly best exemplified by the body of correspondence between the Ickowicz brothers and Anna Radziwiłl - attest a familiarity between the correspondents. Letters were exchanged quite frequently, with a variety of problems touched upon. Should Ickowicz, for instance, not have sent a prompt

${ }^{19}$ The scholars have hitherto categorised royal agents into two groups: (1) titular agents, who maintained no contacts with the court and took advantage of their granted title only in order to receiving tax exemptions or the right to perform a forbidden trade; and (2) real agents, staying permanently and personally in touch with the royal court. It seems, though, that the character of the extant source material would not enable us to actually reconfirm this categorisation. Cf. Maurycy Horn, 'Powstanie i rozwój serwitoratu za Jagiellonów', Biuletyn Żydowskiego Instytutu Historycznego, 3/4 (135/6) (1985), 133-6; Gershon D. Hundert, 'Was there an East European Analogue to Court Jews?', in Paluch (ed.), The Jews in Poland, 69.

20 This custom was also typical to the arrangements with the Christian clients of magnates; LVIA, SA 2423, pp. 435-9, 'Contempt of Mr. Zawisza on Mr. Bohdanowicz'; LVIA, SA 2424, p. 328, 'Decree of Mr. Bohdanowicz with Mr. Zawisza'; LVIA, SA 2425, pp. 340-4, 'Contumacy of Prince Radziwiłł with Mr. Kot, Treasurer'; LVIA, SA 2435, pp. 1227-30, 'Remissyon of Mr. Radziwiłł versus Messrs. Karp'; LVIA, SA 2438, no. 590, 'Contumacy decree re. the case of Dame Skorulska, versus Mrs. Stołłhub and the Jews', 2 March 1749; ibidem, no. 592, 'The case of the Basilian Friars versus the Spouse of the Castellan of Troki and the Jews'. 
reply to Duchess Radziwiłł, she would have expressed a concern about her agent's health. ${ }^{21}$ In some cases, the close and direct contacts had an external dimension to them, with the Jew being allowed to have his lord's ensign displayed at his market-stall. ${ }^{22}$

Apart from the heightened legal status, of importance is the elevation of the social status of royal and magnate agents, which was visible in the Christian society as well as within the Jewish community. The Jews who cooperated with the state treasury became official representatives of the public authorities. Leaseholders and publicans decided for themselves what fees should be credited to the treasury, and who might be exempted from tax. The responsibilities of customs-house administrators included payment of salaries out of customs proceeds to various treasury officials. ${ }^{23}$ Upon leasing out a customs house, collection of liquor taxes or table-land income, the treasurer (podskarbi) undertook to exercise legal care over the leaseholder, and to assist him also in the name of other Commonwealth authorities. ${ }^{24}$ An analogous position was enjoyed by Jewish leaseholders of municipal income: in most cases, apart from overseeing the manufacture of alcoholic beverages, they would manage the City Scales, which enabled them to control the operations of Christian merchants. ${ }^{25}$ The broad use of the assignation system, which consisted in disbursing cash to third persons, on behalf of the magnate, enabled them to turn into official representatives of the magnate authority, acting in multiple situations in the name of their patrons, most of which covered paying of

${ }^{21}$ NIAB, fond 694, op. 3, sect. 28.

${ }^{22}$ Teller, 'The Legal Status', 41-63. For the significance of the right to bear the colour of the magnate patron, cf. Antoni Mączak, Klientela. Nieformalne systemy wtadzy w Polsce i Europie XVI-XVIII w. (Warsaw, 1994), 9.

${ }^{23}$ Biblioteka Czartoryskich [The Czartoryski Library], in Cracow (hereafter: B. Czart.), MS 2583, cards unnumbered: Michał Gordonowicz re. the case of Mr. Cieklewicz, 28 June 1708; ibidem: Jan Szretter to Michał Gordonowicz, 5 March 1709 (re. the case of Mr. Dąbrowski, treasurer); Jan Szretter to Michał Gordonowicz, 18 April 1709 (re. the case of Mr. Kopeć) - as examples of Michał Gordonowicz's activities in the 1st half of 18th c.

${ }^{24}$ Roman Rybarski, Skarb i pieniądz za Jana Kazimierza, Michała Korybuta i Jana III (Warsaw, 1939), 41.

25 Teller, כסף כוח והשפעה, 128-82. It has to be borne in mind, however, that there were localities where attempts were made to restrict this law - Slutsk being an example, where the rule was applied whereby Jewish publicans were obligated to have a Christian scales operator employed. 
a variety of obligations. ${ }^{26}$ General factors enjoyed a special position; in some cases, they would have the right to exercise jurisdiction over the servile people. ${ }^{27}$ An external sign of elevated social status was the manner the Jewish agents were addressed: they were called 'Dear Sir' [Szanowny Pan]; the letters they received, especially from petty nobles, were written in an abject style. ${ }^{28}$

Members of the Jewish economic elites had a somewhat different legal standing within their own community as well. They ranked among the most affluent members of the Jewish society, and formed the last, and most privileged, group of taxpayers. This gave them the right to make decisions regarding the distribution of taxes and election of community authorities; they had it much easier to receive their hazakah (the compulsory permit issued by religious communities for conduct of business operations); and, the so-called sumptuary laws were not pertinent to them. ${ }^{29}$ Those best merited קצי (Kazin) - a title attached only to individuals of high social position. ${ }^{30}$ But their position was somewhat ambiguous, they were criticised by men of religious authority, and excessive assimilation into the Christian environment was imputed to them. ${ }^{31}$ The solicitous performance of the latifundium duties, taking over the power in the kahals within the estates they had taken on lease caused sharp conflicts with their fellow-brothers; this issue will be resumed further on. ${ }^{32}$

${ }^{26}$ Murray [Moshe] J. Rosman, The Lords' Jews: Magnate-Jewish Relations in the Polish-Lithuanian Commonwealth during the Eighteenth Century (Harvard Judaic Texts and Studies, 7, Cambridge, Mass., 1992), 128; Teller, כסף כוח והשפעה, 147-8.

${ }^{27}$ Maria Cieśla, 'Żydzi w Wielkim Księstwie Litewskim 1632-1764. Sytuacja prawna. Demografia. Działalność gospodarcza' (Ph. D. thesis, Institute of History of the Polish Academy of Sciences, Warsaw, 2010), 443-4.

${ }^{28}$ Teller, כסף כוח והשפעה, 91; Marek Sawicki, 'Obraz Żydów w korespondencji szlachty województwa mińskiego w czasach saskich', in Filip Wolański and Robert Kołodziej (eds.), Staropolski oglad świata. Rzeczypospolita między okcydentalizmem a orientalizacja, ii: Przestrzeń kontaktów (Staropolski Ogląd Świata, Toruń 2009), 378.

${ }^{29}$ I. Susis, דער יירישר סיים אין ליטע און ווייסרוסלאנד אין זיין געזעצגעבערישר טעטיגקייט,',

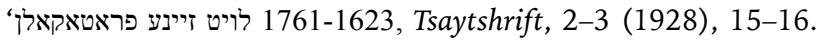

30 Simon Dubnov, פינקס המדינה או פנקס ועד הקהילות הראשיות במדינת ליטא ומשר (Berlin, 1925), 108; Teller, כסף כוח והשפעה, 121.

31 Rosman, The Lords' Jews, 165-6.

32 The extant Hebrew sources offer very prejudiced descriptions of activities of the Ickowicz brothers; cf. Israel Halpern, 'Bunty Woszczyłłowskie', Biuletyn Żydowskiego Instytutu Historycznego, 26 (1958), 28-41. 


\section{III}

HOW THEIR CAREERS DEVELOPED

The Jews formed in the Commonwealth one of the few almost completely literate social groups; most of them were also basically skilled in economy. The conduct of a business was facilitated by their mobility, simultaneous performance of several professions (a typical combination being commerce and income/estate leasehold or, less often, crafts), and economic activities founded upon an efficient network of relatives and associates. ${ }^{33}$ Consequently, compared to members of other social groups, Jews found it easier to develop an economic career. Only very few individuals succeeded in gaining the title of royal or magnate agent, though. Hence, one should consider who the members of Jewish economic elites actually were, what their background was, and what were the factors crucial to the development of their careers in a Christian environment.

We know relatively most on where they resided and what their geographic origin was. Some of the families of the royal agents herein described came from Western Europe - the examples being the Łazarowicz-Mojżeszowicz and Szpeyer families, the latter being eighteenth-century royal agents. The former arrived in the GDL territory from Prague and Frankfurt am Main, probably in the second half of the sixteenth century. ${ }^{34}$ The Szpeyers first appeared in the eastern boundaries of GDL in the former half of the eighteenth century; it seems that their settlement in Mohylev ought to be related with the emigrations of members of economic elite families from the German Reich to the east, as observed in the earlier studies. ${ }^{35}$ It is difficult to unambiguously determine, in either case, which generation settled in the Commonwealth managed to attain a high social position. Most of the royal agents known to us dwelled in large royal cities: the title was most frequently received, especially in the seventeenth century, by citizens of Vilna, which seems fair enough due to the town's capital functions and the royal court that temporarily

${ }^{33}$ Aust, 'Commercial Cosmopolitans', 254.

${ }^{34}$ Cieśla, 'Łazarz Mojżeszowicz', 8; Aust, 'Commercial Cosmopolitans', 150. David B. Ruderman deemed the mobility of Jewish families to be one of the five major characteristics of the Jewish culture in the early modern period; cf. idem, Early Modern Jewry: A Cultural History (Princeton, 2010), 14-15.

${ }^{35}$ Aust, 'Commercial Cosmopolitans', 81-6. 
resided there. ${ }^{36}$ However, in the eighteenth century, the geographic background of royal agents was more diverse. Appointments were increasingly received by residents of Grodno, the fact that ought to be seen in the context of the town's increased significance and its new functions as the location for the sejms (diets) to hold their sessions. ${ }^{37}$ Characteristic of the eighteenth century were also bestowals to the Jews dwelling in small towns belonging to the royal table lands, especially those situated in the northern parts of GDL, which was probably connected with the increased commercial importance of the Königsberg seaport. ${ }^{38}$

It seems that magnate agents would usually get settled as close as practicable to the major magnate domiciles. ${ }^{39} \mathrm{~A}$ high position was attained also by Jews dwelling at the locations of importance to economic development of the latifundia, such as river ports, from which rafting to the most important commercial centres was organised. ${ }^{40}$

Much less is known to us regarding to social background of agents. In many cases, the high position was transferred generation to generation, a process that was evident particularly in the seventeenth and in the first half of the eighteenth century. The seventeenth-century

${ }^{36}$ The citizens of Vilna included: Samuel, Łazarz and Jonasz Mojżeszowicz, Aron Gordon, Salomon Gordonowicz, Abraham Markowicz, Hencel Eliaszowicz; cf. Marceli Kosman, 'Stołeczne funkcje Wilna w dobie przedrozbiorowej', in Ryszard Skowron (ed.), Dwór a kraj między centrum a peryferiami wtadzy. Materiaty konferencji naukowej zorganizowanej przez Zamek Królewski na Wawelu, Instytut Historii Uniwersytetu Jagiellońskiego, Instytut Historii Akademii Pedagogicznej w Krakowie $w$ dniach 2-5 kwietnia 2001 r. (Cracow, 2003), 157-69.

${ }^{37}$ The citizens of Grodno included: Mendel Lejbowicz, Kochman Izaakowicz, Zelman, Judka Szmoyłowicz; cf. Jerzy Gordziejew, Socjotopografia Grodna w XVIII w. (2nd edn, Toruń, 2009), $42 \mathrm{f}$.

${ }^{38}$ In the 1st half of 18th c., appointed royal agents were: Józef Mendelowicz of Gorżdy, Józef Abrahamowicz of Retów, Jozue Moszkowicz of Szawle, Samuel Izraelowicz of Jurbork. For the increased importance of Königsberg in GDL's commerce, see Wasyl Mieleszko, 'Handel i stosunki handlowe Białorusi Wschodniej z miastami nadbałtyckimi w końcu XVII wieku i na początku XVIII wieku', Zapiski Historyczne, xxxiii, 4 (1968), 53-90.

39 The example being Małka, a female agent to the Radziwiłłs of Nieśwież, or the Ickowicz brothers (Biała, Slutsk); Teller, כסף כוח והשפעה, 89; idem, 'The Legal Status', 41-63.

${ }^{40}$ Howsiej Michajłowicz, the long-term leaseholder of Swierzeń, was a close collaborator of Michał Kazimierz Radziwiłł; cf. AR, v, 1546, Supplications of the Jews of Swierzeń, 1736-50. 
Łazarowicz-Mojżeszowicz and Ajzykowicz families may serve as an example, along with those of the eighteenth century - the Gordon and Szpeyer families. ${ }^{41}$ However, some Jewish potentates active in the eighteenth century would not build their careers upon their ancestors' capitals - the Ickowicz brothers or Kochman Izaakowicz, the royal agent in Grodno. ${ }^{42}$

We know very little on the educational standard of the Jewish royal and magnate agents. They gained their basic economic and, plausibly, linguistic skills by practising under the guidance of their fathers. ${ }^{43}$ Some of the royal agents also received a secular education. The group under analysis includes doctors studying at foreign universities. ${ }^{44}$ The contemporary religious authors reprimanded members of the economic elites for their promoting of secular education of children. ${ }^{45}$ Members of the group under research had certainly been through a basic religious instruction. It may be supposed that royal agents coming from renowned rabbinical families studied also in higher religious schools. ${ }^{46}$

${ }^{41}$ LM, 146, pp. 711-12, 'Letter of affirmation for the Pawluszczycs versus the Jewish customs administrators', 24 July 1693; AR, xxiii, 32/3; Maria Cieśla, 'The Jewish Economic Elite in the Great Duchy of Lithuania in the 17th and 18th Century', in Simonetta Cavacciochi (ed.), The Economic Role of the Family in the European Economy from the 13th to the 18th Centuries (Atti delle 'Settimane di Studi" e altri Convegni, 40, Firenze, 2009), 497-509.

42 Teller, כסף כוח והשפעה, 89 ff. On Kochman Izaakowicz, see LMAB, 139, no. 1841: his correspondence with Antoni Kazimierz Sapieha.

${ }^{43}$ Cieśla, 'The Jewish Economic Elite', 500; on their command of languages and skill of moving about in a culturally alien environment, cf. Scott Ury, 'The Shtadlan of the Polish-Lithuanian Commonwealth: Noble Advocate or Unbridled Opportunist', Polin, 15 (2002), 291. More on language skills, cf. Daniel Stone, 'Knowledge of Foreign Languages among Eighteenth Century Polish Jews', Polin, 10 (1997), 200-18.

${ }^{44}$ Louis Lewin, 'Die jüdischen Studenten an der Universität Frankfurt an der Oder', Jahrbuch der Jüdisch-Literarischen Gesellschaft, xv (1923), 61-96; David E. Fishman, 'Science, Enlightenment and Rabbinic Culture in Byelorussian Jewry, 1772-1804' (Ph. D. thesis, Harvard University, 1985), 27. Also, cf. Andrzej Wyrobisz, 'Lekarze jako wolny zawód i grupa społeczna w miastach późnośredniowiecznej i wczesnonowożytnej Europy', in Michał Kopczyński and Antoni Mączak (eds.), Gospodarka, ludzie, władza. Studia historyczne ofiarowane Juliuszowi Łukasiewiczowi w 75 rocznice urodzin (Warsaw, 1998), 61-71.

${ }^{45}$ Stone, 'Knowledge of Foreign Languages', 200.

${ }^{46}$ The legends related to Saul Wahl and Aron Gordon seem to confirm such a hypothesis. Both Saul Wahl and Gordon, being royal agents, are reported to have 
On considering the issue of social descent, the question should be asked about how the economic elite related to the rabbinate elite. Being born to a known rabbinical family could facilitate the development of one's career, since the relatives dwelling in various places were the excellent prospective partners in business. This problem is however difficult to investigate, due to the specificity of the extant sources. We usually do not know the Jewish names of elite members, which would enable to identify the persons in Jewish sources. It is hard to hypothesise based on individual instances; as shown by the sources, members of known rabbinate families were active in the milieu of Jewish economic elites. It is not known, though, whether this phenomenon was typical or resulted from a purposeful policy of the families; similarly, no differences are identifiable between the seventeenth and eighteenth century. It is only known that Heliasz Ajzykowicz, a royal agent active in the latter half of the seventeenth century, was born to the known rabbinical family of Shorr. ${ }^{47}$ In spite of his unorthodox views, Yekutiel Gordon developed his rabbinical career, but the fact that his activity is known to us only from the Jewish sources, for a change (and we do not know his Polish cognomen) makes it impossible to determine the exact degree of relationship between him and bearers of the surname Gordon that are known from the Polish sources. ${ }^{48}$

In most cases, the conferment of the title of royal or magnate agent came as the crowning of the earlier long-lasting cooperation of the Jewish individual with the kingdom or court treasury. For such career to be initiated, indispensable were his economic skills whose

received a religious education with foreign yeshivas, see Maria Cieśla, 'Legenda o jednodniowym królu Saulu Wahlu - jej geneza oraz znaczenie dla funkcjonowania Żydów w społeczeństwie Wielkiego Księstwa Litewskiego', in Urszula Augustyniak (ed.), Tradycja - metody przekazywania i formy upamiętniania $w$ państwie polsko-litewskim, XV-pierwsza potowa XIX wieku (Warsaw, 2011), 33-44.

${ }^{47}$ AR, xxiii, 135/6, p. $274 \mathrm{v}$, an extant Hebrew signature of Ajzykowicz; the Shorr family members for many years held the office of rabbi of Brest (Polish: Brześć), cf. Arye Leyb Finstein, עיר תהילה. כל הקורות לעדת ישראל שבעיר בריסק (Warsaw, 1886).

${ }^{48}$ On Yekutiel Gordon, cf. Yoseph Dan, Gordon, Yekutiel Ben Leyb, in Encyclopaedia Judaica: Second Edition, ed. Fred Skolnik, vii (Detroit, 2007), 769; Isaiah Tishby, נתיבי אמונה ומינות: מסות ומחקרים בספרות הקבלה והשבתאות. (Ramat Gan, 1964), 169-72; on Gordon's activities as physician in GDL, cf. Fishman, 'Science, Enlightenment', 41-7. 
importance was all the higher that the Commonwealth's treasury system had no permanent administration. State taxation was administered in GDL by the Treasurer who dealt with the collection or leased the proceeds, through his hired officials. When it came to leasing, the principle of tendering procedure was at work: the contract would be signed with the individual who had offered the highest amount. Such solutions have prevented the evolvement of a group of treasury administration professionals: the team tasked with such responsibilities would be replaced together with the Treasurer. Collaboration with the treasury was of special importance in career development in the seventeenth century, which is well illustrated by the careers of the Łazarowicz-Mojżeszowicz brothers, or Hirsz Izraelowicz, who leased state income some dozen years before getting officially appointed. ${ }^{49}$ In the eighteenth century, the increasingly frequent reason for appointment of royal agents was the Jewish individual's earlier commercial operations. This is visible particularly in the appointments made by Augustus II immediately after the Northern War ended. ${ }^{50}$ It is plausible that those Jews who received their appointments in the early eighteenth century had started collaborating with the king during the war, providing supplies to the army. ${ }^{51}$

${ }^{49}$ LM, 149, p. 112, 'Scribe patent charter for the Dyneburg [customs] house, to Irsz Izraelowicz', our agent, 20 Feb. 1698; LM, 159, p. 262, 'Letter of affirmation to the infidel Jew Pinkas Izaakowicz', 27 Nov. 1714; LM, 109, p. 25, 'Serwitorat to Mojżesz Łazarowicz', 5 March 1633; ibidem, p. 26, 'Serwitorat to Lazarz Mojżeszowicz', 5 March 1633; ibidem, p. 26, 'Serwitorat to Samuel Mojżeszowicz', 5 March 1633.

${ }^{50}$ After the Northern War ended, the following were appointed as agent: Józef Abramowicz (LM, 160, p. 665, 28 Feb. 1721); Józefowicz Mendelowicz (ibidem, p. 664, 28 Feb. 1721); Abram Beniamin Szpeyer (LM, 169, p. 146, 4 Dec. 1715); Sapowicz Jochimowicz (LM, 154, pp. 213 f., 25 Feb. 1710); Pinkas Izaakowicz (LM, 159, p. 22, 10 Jan. 1713); Aron Gordon (ibidem, p. 144, 16 March 1713); Zelman (ibidem, p. 264, 27 Nov. 1714); Pinkas Izaakowicz (ibidem, p. 262, 27 Nov. 1714); Kochman Izaakowicz (ibidem, p. 393, 25 Nov. 1718); Salomon Gordonowicz (ibidem, p. 32, 24 Feb. 1717); Samuel Izraelowicz (ibidem, p. 320, 24 Feb. 1717); Abraham Markowicz (ibidem, p. 471, 3 April 1720); Hencel Eliaszowiczowicz (ibidem, p. 472, 3 April 1720); Juda Szmoyłowicz (ibidem, p. 518, 14 Feb. 1720); a Jew of Szawle [no name quoted] - LM, 162, pp. 219-20, 24 Nov. 1724.

${ }^{51}$ As shown by the studies on the West-European matters, supplying the army in the course of the war was quite frequently one of the first steps in the economic career of the Jewish potentates; cf. Aust, 'Commercial Cosmopolitans', 148-51; 
Well-educated Jewish physicians also tended to be employed at the royal court. ${ }^{52}$

Magnate patronage was of importance for the development of royal agents' careers. Magnate wardens were usually helpful in establishing the first contacts with the royal court, using the Jews as agents in operating state leaseholds, and supporting them in their striving for promotion with the royal court. ${ }^{53}$ The family of Łazarowicz-Mojżeszowicz clearly shows the importance of contacts with the Lithuanian magnates, as well as how the careers of Jewish agents were associated with the political careers of their Christian patrons. Mojżesz Łazarowicz and his sons were appointed royal agents at the moment Krzysztof Radziwiłl, one of their magnate patrons, got reconciled with the court and resume active political activity. ${ }^{54}$ Similar processes were also observable in the eighteenth century, a good example being the Gordon family, whose careers were based on their cooperation with the Ogiński family. ${ }^{55}$

One finds it more difficult to determine the drivers behind the careers of magnates' agents. This title was primarily given to general leaseholders of magnate estates, who often pursued, in parallel, a commercial activity, providing supplies to the courts of their magnate patrons; artisans working for the court would be appointed an agent with a magnate less often. Decisive for the promotion was a personal

Michael Graetz, 'עלייתו ושקיעתו של ספק הצבה היהודי: כלכלה יהודית בעתות מלחמה', Zion, lvi (1991), 255-73.

52 Lewin, 'Die jüdischen Studenten', 64; Yoseph Kaplan, 'Court Jews before the Hofjuden', in Mann, Cohen and Backhaus (eds.), From Court Jews, 16. One of best known Jewish physicians in the Commonwealth was Mojżesz Fortis, cf. Rosman, The Lords' Jews, 147-54. The court medics' milieu usually consisted of many foreigners, cf. Wojciech Tygielski, Wtosi w Polsce XVI i XVII w. Utracona szansa na modernizacje (Warsaw, 2005), 265-70.

${ }^{53}$ Also the Christian nobility could enjoy promotions owing to their cooperation with magnate courts; for more on the importance of the contacts between nobles and magnates for the development of noblemen's careers, cf. Pośpiech and Tygielski, 'The Social Role', 85-9.

${ }^{54}$ Cieśla, 'Łazarz Mojżeszowicz', 14. On the political activity of Krzysztof Radziwiłł, cf. Urszula Augustyniak, Dwór i klientela Krzysztofa Radziwitła (15851640). Mechanizmy patronatu (Warsaw, 2001), 14-27.

${ }^{55}$ Cieśla, 'The Jewish Economic Elite', 503. It is also known that Mojżesz Beniamin Szpeyer was a collaborator of Jerzy Jan Sapieha (Vilniaus Universiteto Biblioteka [hereafter VUB], 59/6, pp. 3-4), whereas Kochman Izaakowicz was a protégé of Antoni Kazimierz Sapieha (LMAB, 139, no. 1841). 
contact with the protector, along with financial abilities and success in the business they conducted, as well as long-standing cooperation and, possibly, the magnate's individual likings.

The development of the careers of members of Jewish economic elites was also facilitated by the peculiar position they enjoyed within the Jewish community and in the Christian environment. In describing the bonds between members of the Jewish economic elite and various social groups, in terms of cliental ties, the former group ought to be ascribed the function of so-called brokers. ${ }^{56}$ They most often were patrons of their own cliental network, composed of a number of Jewish and, less often, Christian associates who offered services to their Christian carers through their Jewish patrons. ${ }^{57}$ As part of such arrangements, Jewish agents became holders of remarkable incomes and of certain privileges stipulated for royal or magnate court's closest collaborators. This arrangement was quite advantageous also from the standpoint of the royal or magnate court, since the Jews who offered a cooperation managed a network of well-qualified co-operators who, by agency of their Jewish patron, contributed to an economic success.

It remains but a supposition that an earlier involvement with Jewish religious-community authorities was possibly an additional factor facilitating the commencement of a career in the Christian environment. It was a frequent practice in GDL that general leaseholds of proceeds were transferred to the kahal authorities, which subsequently leased out parts thereof. By signing on behalf of the religious community a contract for such lease, the kahal representative

${ }^{56}$ Antoni Mączak, Nierówna przyjaźn. Układy klientalne $w$ perspektywie historycznej (Wrocław, 2003), 18; idem, 'Przestrzeń w strukturze państwa wczesnonowożytnego. Refleksje nad regionem w życiu szlachty polskiej’, in Ewa Dubas-Urwanowicz and Jerzy Urwanowicz (eds.), Miasto, region, spoteczeństwo. Studia ofiarowane Andrzejowi Wyrobiszowi w sześćdziesiąta rocznice Jego urodzin (Białystok, 1992), 199-206.

57 The detailed number of co-operators of the Jewish magnate or royal agents is difficult to estimate. Indicative of this volume are the Ickowicz brothers. After Szmoyła Ickowicz was accused of betrayal and misappropriation of Radziwiłł's money, fifty-three persons were imprisoned, all Szmoyła's family members and his closest associates, cf. AR, vii, 707, 'Specificatyon of the Jews taken to custody', 15 July 1745. Also, cf. the correspondence between Szmoyła Ickowicz and Anna Radziwiłł, née Sanguszko, with the latter frequently requesting the former for settling matters with the Jews who also worked on the court's order; NIAB, fond 694, op. 3, sect. 28 . 
gained the opportunity to establish contacts in the court milieu and simultaneously to build his own cliental network, which was enormously helpful for the development of his own career. ${ }^{58}$

A career path in the Christian environment was the case with only few. It happened that not all the brothers and cousins working for one family business succeeded in gaining so high a social position. The Łazarowicz-Mojżeszowicz family serves as an excellent example: of the three brothers - Samuel, Łazarz and Jonasz - only Łazarz succeeded in winning the title of royal secretary. Samuel's son, Pinkas, who was active at that same time, was not even nominated as a royal agent. ${ }^{59}$ Clearly, those who attained the highest positions not only had to display adequate skills or capitals but also character traits that enabled them to have a career in a culturally alien and not always friendly environment. It may only be speculated what features they had to display: mind and wit, adaptability to situations, aptitude for learning, good interpersonal and communication skills, stubbornness and resoluteness were certainly among them.

\section{IV \\ STRATEGIES OF ECONOMIC ACTIVITY}

Members of the Jewish economic elites usually acted as administrators managing fair-sized enterprises, dealing with lease of proceeds and estates, commerce, as well as banking. Lease of state incomes was the basis of the economic operations of royal agents. There was no permanent treasury apparatus functioning in the Commonwealth; state proceeds were leased. Due to their economic skills and ability to mobilise capitals at a fast pace, Jews in GDL monopolised the leaseholds of state incomes; the phenomenon appears typical to the seventeenth century and the first half of the eighteenth century. In most cases, they took over customs duties on lease, and many a time contracted for lease of taxes on manufacture and sale of liquors (czopowe [liquor excise tax] and szelezżne [tax paid by burghers, at 10 per cent of the amount of liquor they have sold]). The largest potentates succeeded in simultaneously receiving the leases of several

${ }^{58}$ For the importance of leaseholds given away to the kahal authorities, cf. AR, xxiii, $135 / 6$, pp. 86-9.

${ }^{59}$ Cieśla, 'Łazarz Mojżeszowicz', 13. 
various taxes; Łazarz Mojżeszowicz was a rather exceptional case, as in the middle of seventeenth century he held most of GDL's treasury incomes on lease. ${ }^{60}$ The sources have also recorded individual cases of general leaseholds - i.e. such which extended to all the GDL's customs-based incomes. ${ }^{61}$ More frequently, however, did the royal agents lease a single type of tax within a specified territory - e.g. one of the customs houses or the czopowe and szelezine for a given county (powiat). It happened that leases of this sort were held for quite a long time. ${ }^{62}$

The magnate and royal agents also dealt with commerce. This area grew particularly important for the latter when in the second half of the seventeenth century a ban was launched on provision of state leaseholds to Jews. Through their close trading contacts with Königsberg and Riga, Jewish merchants provided to the Prussian market animal hides, hemp, porcine hair and wax, and imported thence fabrics and spices to supply the magnate courts and the royal court with. These activities made them even stronger attached to the magnates of GDL. ${ }^{63}$

The magnate or royal patronage was quite of importance for the development of the careers of the Jewish economic elites. In order to achieve the best results practicable, the Jews endeavoured to ensure a double protection for themselves. In most cases, royal agents were

${ }^{60}$ Ibidem, $15 \mathrm{f}$.

${ }^{61}$ Eliasz Izraelowicz and Icek Zelmanowicz leased all the GDL customs duties in 1698; Berens Leyman held a corresponding lease in 1705; AVAK, vol. 29, no. 129, 'The GDL customs-duties transferred, in their entirety, to Eliasz Izaakowicz, 24 July 1698'; LVIA, SA 2419, f. 68, 'Contempt of court to His Excellency Starost of Samogitia, Field Hetman of the GDL, on Berens Leyman, a Jew', 28 March 1705. On the organisation of state leaseholds, cf. Rybarski, Skarb i pieniadz; Anna Filipczak-Kocur, Skarbowość Rzeczypospolitej 1587-1648. Projekty - ustawy - realizacja (Warsaw, 2006).

${ }^{62}$ LM, 159, pp. 476r-v, 'Confirmation of the contract for our customs-duty to the infidel Pinkas Izaakowicz', 3 April 1720 - leasehold of one customs house. Also, cf. settlements with leaseholders of czopowe and szelężne in the individual counties (powiats) of GDL: LVIA, SA 2318, 3410, 3411, 3413, 3416, 3429, 3439, 3444, 3454, 3450, 3452; VUB, F. 5-D1520/1546; AR, ii, 1578.

${ }^{63}$ B. Czart., MSS 2582, 2585; AR, xx, 4, 'Register of expenses on these commodities transferred to Riga and from Riga, Heliasz Izaakowicz’, 1672; also, cf. preserved accounts from the settlements with Małka and Mazurka, in provision of supplies to Radziwiłł courts, AR, xxi, A 221. 
also close collaborators of magnates. The magnate favouritism was of importance not only at the verge of their careers but also later on, as it provided an extra security in case of any misfortune. A magnate agent would normally cooperate with several magnate families, as perfectly illustrated by the Ickowicz brothers who partnered both the Radziwiłłs and the Czartoryskis. ${ }^{64}$

Business was most often done through a network of associates, most of whom were sorted by the family key. Parents, wives, adult children, and cousins were all involved in business operations. Responsibilities in most cases were distributed in a specific way between the father and his sons, or among the brothers. This is excellently illustrated by the case of Mojżesz Łazarowicz, who would assign performance of a variety of tasks to his sons. ${ }^{65}$ The active involvement of the wives was of great importance, particularly in the conduct of wide-ranging financial operations. Women many a time replaced their husbands when they were away; this practice, which was decisive about the family business's economic success, has been attested by Adam Teller, who uses the example of the wives of the Ickowicz brothers. With the whole family involved, the enterprise increased its competitive edge against its Christian counterparts, as the costs of its operations were reduced and unlimited availability and flexibility guaranteed. ${ }^{66}$

It sometimes proved necessary to complement the family network by Christian partners, but the available source materials shows that the Christians only performed auxiliary functions in the Jewish enterprises. ${ }^{67}$ Family businesses applied a number of methods in order to

${ }^{64}$ Cieśla, 'The Jewish Economic Elite', 497-509.

${ }^{65}$ LMAB, 139, no. 2883.

66 Avraham Grosman, 'הזיקה בין כלכה הכלכלה במעמד האישה יהודיה באשכנז הקדומה), in Menahem Ben-Sasson (ed.), דת וכלכלה יחסי גומדין 'Jerusalem, 1995), 156-9; Jacob Katz, Tradition and Crisis: Jewish Society at the End of the Middle Ages, trans. Bernard Dov Cooperman (New York, 1993), 113; Teller, 9סף כוח והשפעה, 97ikel of Hammeln was the best-known Jewess pursuing wide-ranging businesses, cf. Chava Turniansky, גליקל זיכרונות 1719-17919 (Jerusalem, 2007); Natalie Zemon Davis, Women on the Margins: The Seventeenth's Century Lives (Cambridge, Mass. and London, 1995), 12-41.

${ }^{67}$ The source material concerning the period and geography under analysis does not actually support the thesis, as recently proposed by C. Aust, whereby cooperation in Jewish enterprises was founded on mutual trust, hence the associates were selected not with regard to their confession, cf. eadem, 'Commercial Cosmopolitans', 126-37. 
earn the best possible economic results. Most Jewish entrepreneurs endeavoured to build a possibly most efficient network of contacts, which would cover the entire country. The detailed studies devoted to the Łazarowicz-Mojżeszowicz family have shown that the members of this clan were sent to work in various commercial hubs of GDL. ${ }^{68}$ It may be supposed that the Jewish magnate and royal agents also created international contact networks; the condition of the extant sources would not allow to confirm this hypothesis, though.

$\mathrm{V}$

\section{EVERYDAY LIFE}

The daily life of the Jewish economic elites is the most interesting aspect, but is the hardest to present; it is only re-constructible in an outline. Certain elements of nobility's lifestyle were taken over by them; whilst not specific to the Jews, the phenomenon took a different course, and implied different consequences. Affluent burghers ended up becoming part of the nobility estate, on a more or less formal basis. ${ }^{69}$ With the Jewish elite, we can only speak of an adaptation and modification of certain cultural patterns; this process bore fruit in the formation of a peculiar subculture which resulted from a combination of elements of traditional Jewish culture and the most attractive, outward elements of noble culture, such as the dwelling and dressing style. ${ }^{70}$

A long-standing cooperation with the royal and/or magnate court and economic activities enabled the Jews, in a different scope, to amass a considerable fortune. Capitals were in most cases invested in real properties - tenement houses in towns, suburban granges, manors. ${ }^{71}$ Apart from realties, they also possessed fair financial resources.

${ }^{68}$ Cieśla, 'The Jewish Economic Elite', 497-509.

${ }^{69}$ Maria Bogucka, 'Miejsce mieszczan w społeczeństwie szlacheckim: atrakcyjność wzorców życia szlacheckiego w Polsce XVII w.', in eadem, Cztowiek $i$ świat. Studia z dziejów kultury i mentalności XV-XVIII w. (Warsaw, 2008), 63-75.

${ }^{70}$ Such a model of acculturation was typical to the Jewish economic elites not only in the Commonwealth; in the early modern period, acculturation did not imply secularisation or assimilation, cf. Kenneth Stow, Theatre of Acculturation: The Roman Ghetto in the Sixteenth Century (Seattle etc., 2001), 8; Ivan G. Marcus, Rituals of Childhood: Jewish Acculturation in Medieval Europe (New Haven, 1996), 11.

${ }^{71}$ Cieśla, 'The Jewish Economic Elite', 497-509. 
It seems that Łazarz Mojżeszowicz was one of the largest Jewish potentates in the history of GDL: as of 1661, he estimated his assets at "eleven one-hundred-fold thousand seven thousand eight-hundredand-sixty zloty", that is, $1,107,860$ zloty ${ }^{72}$ Also the Jews collaborating with magnates succeeded in amassing appreciable substance; the Ickowicz brothers are a good example: they had eighteen real estates in Slutsk alone. The wealth of these brothers is attested by a preserved inventory of their movables, where the number and the quality of the entered objects goes much higher above the middling nobility's standard. ${ }^{73}$

The Jewish potentates' lifestyle was very mobile; they visited fairs and kermises in the whole of Eastern Europe, inspected the leased estates, and paid visits to their patrons' courts. ${ }^{74}$ They usually owned houses and manors across the country, but established their main residences in larger towns. We know very little of what those abodes looked like and how they were equipped. The Ickowicz brothers' inventories offer us a few details, but this source is specific, as it was compiled as piece of evidence for use in a trial on misappropriation of Hieronim-Florian Radziwiłł's money. What those inventories have primarily recorded is valuable objects, whereas the furniture or, say, daily necessities of lesser value, are completely neglected..$^{75}$ It is easy to jump on this basis to conclusions regarding the wealth or lifestyle. The inventories take record of expensive ornaments: mirrors, carpets, candelabra; ${ }^{76}$ fabrics and carpets embellished with Oriental motives, typical to the period, were certainly part of the

${ }^{72}$ AR, xxiii, 135/6, pp. 268-75, 'Copy from an extract of the Testament of Łazarz Mojżeszowicz, a Jew, Administrator of the customs and Secretary to HRM'.

${ }^{73}$ NIAB, fond 694, op. 1, no. 51, pp. 341-7; cf. Andrzej Pośpiech, Pulapka oczywistości. Pośmiertne spisy ruchomości szlachty wielkopolskiej z XVII w. (Warsaw, 1992), 77-121.

${ }^{74}$ Aust, 'Commercial Cosmopolitans', 137-46; Wolfgang Treue, 'In die Jeschiwe und auf den Jahrmarkt: Jüdische Mobilität in Aschkenas in der Frühen Neuzeit', in Rolf Kießling et al. (eds.), Räume und Wege. Jüdische Geschichte im Alten Reich 1300-1800 (Berlin, 2007), 191-207.

${ }^{75}$ For analysis of the realty inventories, cf. Pośpiech, Pułapka oczywistości; Urszula Augustyniak, 'Inwentarze mienia radziwiłłowskiego z XVI-XVII wieku jako źródło do historii mentalności i życia codziennego - możliwości badań', Kwartalnik Historii Kultury Materialnej, li, 2 (2003), 231-49.

${ }^{76}$ Silver, embellished and plain mirrors, gilded, brass, floor and pendent candlesticks are entered in the inventories; NIAB, 694, op. 1, no. 51, pp. 342-7. 
amenities. ${ }^{77}$ Sets of silver dishes ornamented with precious stones, arms - cold steel (sabres) and firearms, horses, carts and cabs draw one's attention as well. ${ }^{78}$ The Ickowiczs' manor also housed an impressive book collection - totalling over a thousand of recorded volumes - which was used in their private synagogue. ${ }^{79}$

The Ickowiczs' realty inventories enable one to infer that clothes were worn in those places according to the binding fashion. Christian apparels were in use; outfits described in the inventories as Jewish were worn less often, probably only at high days. Astonishingly, however, and contrary to the earlier research, these garments were very colourful. ${ }^{80}$ The inventories also mention considerable amounts of jewellery and richly embellished women's headgears. ${ }^{81}$

External acculturation and assumption of certain Christian models did not lead to quitting Judaism. No conversions to Christianity would

${ }^{77}$ Gedal and Szmoyła's inventory mentions Persian and Chinese upholsteries, see ibidem.

${ }^{78}$ Łazarz Mojżeszowicz, after an assault in Kamień, reported on a sabre having been stolen from him; Szmoyła Ickowicz's realty inventory has: "Rifle, one, brassclad all over"; "Rifle, brass-clad, forced-apart"; "Shot-gun, military, brass-clad"; "Old guns -6 , whereof three without a lock". As it seems, these arms were of no practical use, but served as a decoration in the Ickowiczs' house; cf. Nina MiksRudkowska, 'Wnętrza mieszkalne w miastach polskich w drugiej polowie XVII i w XVIII w.', in Mirosława Gajewska (ed.), Dom i mieszkanie w Polsce (druga połowa $X V I I-X I X$ w.) (Studia i materiały $z$ historii kultury materialnej, 50, Wrocław etc., 1975), 111; Cieśla, 'Łazarz Mojżeszowicz', 25; NIAB, 694, op. 1, no. 51, pp. 344-7. Gedal Ickowicz's inventory mentions 12 horses, while Szmoyła had 42 horses; the inventories moreover specified: carts, calashes, kibitkas (type of covered wagon), carriages, see ibidem, pp. 341-7.

79 The Ickowicz brothers had over 1,000 books in Slutsk; regrettably, an inventory taken by Christian clerks specifies no titles - we do not even know whether the books were Hebrew or Yiddish, see ibidem, pp. 341-7.

${ }^{80}$ The Ickowiczs' inventory describes very few garments as 'Jewish', i.e.: "A Jewish mętlik, satin, green, with a wide silver company"; "A Jewish mętlik, made of crimson satin, [with] pasamons [braids], satin, green"; "A Jewish żupan, white, with white hook-and-eyes"; "Men's school attire, black, of graditur [thick French silk]", see ibidem, pp. 344-7. These mentions of Jewish apparels seem to contradict Irena Turnau's statement about the Jews preferring black attires, see eadem, 'Ubiór żydowski w Polsce XVI-XVIII wieku', Przeglad Orientalistyczny, 3 (143) (1987), 297-311.

${ }^{81}$ The Ickowiczs' inventory features e.g.: “a woman's cap embroidered with gold and pearls", NIAB, fond 694, op. 1, no. 51, pp. 342-7. 
occur in this milieu in the period under discussion. ${ }^{82}$ Representatives of the elites were active members of Jewish religious communities, particularly in the seventeenth century; some of them held community offices, primarily as parnas (community head) or shtadlan (official community representatives) ${ }^{83}$ Thanks to the intercession of influential royal agents, much beneficial privileges were often successfully gained for the communities. ${ }^{84}$ Such agents also held functions in highranking Jewish autonomy bodies - the Lithuanian Wa'ad, inheriting them, in some cases, within their families for several decades. ${ }^{85}$ They conducted extensive foundational activity, supporting the construction of synagogues, sponsoring their furnishings and supporting the development of religious studies. ${ }^{86}$

The Jewish elites' attitude to the communities somewhat changed in the eighteenth century, the example of Szmoyła and Gedal Ickowicz offering a good illustration of the process. In spite of their attachment to religion, their religious activities were no more confined within the existing communities. The Ickowiczs used the kahals instrumentally, endeavouring through the control over the communities to achieve additional income and to improve their social position by purchasing rabbinate offices for their sons-in-law. Conflicts arousing from this were a frequent thing. ${ }^{87}$ It also seems that being appointed royal agent

82 The Jewish economic elites' attitude toward Christianity is very well rendered by the story of Mojżesz Fortis, Jewish physician, agent to Elżbieta Sieniawska: in spite of his good knowledge of the New Testament and the promises of social promotion and financial considerations he was promised, he eventually resisted to the proposals to convert; see Jakób Radliński (trans.), Prawda chrzesciańska od nieprzyjacielá swego zeznana, to iest Traktat rabina Samuela pokazujacy błędy zydowskie około zachowania Prawa Moyzeszowego y przyścia Messyaszowego, ktorego Zydzi czekáia, z Lacińskiego ięzyka na Polski (Lublin, 1733), 37. For more on Mojżesz Fortis, see: Rosman, The Lords' Jews, 147-54.

${ }^{83}$ Ury, 'The Shtadlan', 267-301.

84 The intercession of Łazarz Mojżeszowicz has led to the issuance of privileges for most Jewish communities in GDL, see Cieśla, 'Łazarz Mojżeszowicz', 22.

${ }^{85}$ Members of the Gordon family participated in the Wa'ad authorities for several dozen years; characteristically, the deceased father was replaced in office by his son.

${ }^{86}$ AR, xxiii, $135 / 6$, pp. 268-75, 'Copy from an extract of the Testament of Łazarz Mojżeszowicz, a Jew, Administrator of the customs and Secretary to HRM'.

${ }^{87}$ Adam Kaźmierczyk, 'Konwersja, jichus i walka o władzę w ziemstwie krakowsko-sandomierskim w latach czterdziestych XVIII wieku', in Agnieszka 
was in the eighteenth century a means to solve in-kahal conflicts. It is striking that some individuals who gained the nomination from Augustus II and Augustus III were rabbis who endeavoured thereby to strengthen their own position in their kahals. Being granted the title implied, moreover, their release from the responsibility for the kahal's debts. ${ }^{88}$

It seems that the religious needs of Jewish eighteenth-century potentates were satisfied in smaller communities. As is known, the Ickowiczs maintained a private synagogue at their manorial estate in Slutsk; it was richly furnished, with a library of more than a thousand books amassed. ${ }^{89}$ The popularity of heresies and religious novelties among the Jewish economic elites remains open to debate. Their contemporary orthodoxy guardians accused the affluent Jews of sympathising with the Sabbatean heresy. ${ }^{90}$ The example of Yekutiel Gordon, who was charged with propagation of Sabbatainist views, seems to confirm these accusations, but a premise like this is too faint to formulate any well-informed hypothesis upon. The Hasidic tradition has preserved a story on Szmoyła Ickowicz's contacts with

Jagodzińska (ed.), W poszukiwaniu religii doskonałej? Konwersja a Żydzi (Wrocław, 2012), 30-47.

${ }^{88}$ LM, 159, pp. 262-3, 'Letter of patronage to the infidel Henzel Szaulowicz, Rabbi of Grodno', 27 Nov. 1717; ibidem, pp. 123-4, 'Rescript for the infidel Jews of Grodno, Faywisz Aronowicz and Zelman Berkowicz', 11 March 1713.

${ }^{89}$ NIAB, fond 694, op. 1, no. 51, pp. 344-7, 'Specificatyon of the things carried from the Cashier's manor into the new castle, and that is, silverware, fabrics and cloths, and a variety of commodities as expressed hereunder'; this inventory mentions the following items from the synagogue: "Boards, various, as due with the school, one item; of the large ones, together with the smaller ones, nine; handles, five; there is glass placed between them. ... Crown with bells, for school use and set with scarlet gems; crown with a board and holster, for school use; ... school washing-tub for washing the hands"; "In the Jewish school, books placed upstairs - 908; old books, 277".

${ }^{90}$ Such accusations appear in the writings of Jacob Emden and Moses Hagiz, cf. Gershom Sholem, 'מחקרי שבתות, 'מיות על השבתאות בספר המיסינרים במאה הי"ח', in idem, (Tel Aviv, 1991), 617 f. On the economic elite's interest in Sabbatanism we are also informed by the diaries of the missionaries of the Institutum Iudaicum of Halle, who during their missionary travels several times noted down the stories concerning a former physician, King John III Sobieski's agent, who subsequently is said to lead a group of Sabbateans settled in Führt, cf. Johann H. Callenberg, Dreyzehnte Fortsetzung seines Berichts von einem Versuch das arme jüdische Volck zur Erkenntniß der christlichen Wahrheit anzuleiten (Halle, 1735), 231. 
Baal Shem Tov, the founder of Hasidism, who is said to have visited the Ickowiczs in Slutsk and bless their newly-constructed house. ${ }^{91}$

Not much more can be said of the system of values observed by the Jewish elites. The available sources allow us to describe a few very general traits which seem not to have been peculiar to the Jewish economic elites. As we can learn from Łazarz Mojżeszowicz's will, family ties were very important for him; the relatives were not merely daily business partners. Characteristically, Mojżeszowicz described in his last will a dream wherein his mother, who had died earlier, told him of his nearing death and prescribed where he was to be buried. This same source tells us that education was of value as well: among his relatives, Łazarz distinguished his son-in-law who was a rabbi..$^{92}$

Łazarowicz-Mojżeszowiczs, Ajzykowiczs, Gordons, Ickowiczs are just the individual examples of Jewish entrepreneurs who succeeded with their careers in the Christian environment. Their many years' cooperation with the royal court or with the magnates' courts and family-based method of doing business enabled them to make substantial fortunes and achieve a high social position. In spite of this, they remained loyal to their religion and culture, even though their views might have fundamentally deviated from the orthodoxy. These few selected examples show that they were closer in their style and standard of life to the nobility, if not the magnates, than to their indigent fellow brothers. Research on the Jewish economic potentates has shown that the Jewish population in the Polish-Lithuanian Commonwealth was quite diverse. Since, however, no generalisation can be made based on these few examples, it appears extremely important that research be continued with respect to the social diversities within the Jewish community in the Polish-Lithuanian Commonwealth.

trans. Tristan Korecki

${ }^{91}$ Adam Teller, 'מסרת סלוצק על ראשיתו של הבש'ט', in Immanuel Etkes, David Assaf, and Joseph Dan (eds.), מחקרי חסידות (Jerusalem Studies in Jewish Thought, 15, Jerusalem, 1999), 15-38; Halpern, 'Bunty Wołłoszczyłłowskie'; A. Kaźmierczyk recently posed a research query about their attitude to Sabbataism and Hasidism; this issue calls for further research, though; see idem, 'Konwersja, jichus', 47.

${ }^{92}$ AR, xxiii, 135/6, p. 274. 